\title{
Poverty Analysis and Factors Which Affects Indonesia
}

\author{
Nur Yuliany ${ }^{1}$, Nursini $^{2}$, Madris $^{3}$, Agussalim $^{4}$ \\ \{nur.yuliany@uin-alauddin.ac.id ${ }^{1}$, nini_mahmud@yahoo.com ${ }^{2}$, madriskandar@gmail.com ${ }^{3}$, \\ agusjerox@gmail.com ${ }^{4}$ \} \\ UIN Alauddin Makassar ${ }^{1}$, Universitas Hasanuddin Makassar², Universitas Hasanuddin Makassar ${ }^{3}$, \\ Universitas Hasanuddin Makassar ${ }^{4}$
}

\begin{abstract}
Poverty is one of the problems that humans always face. Poverty is as old as humanity itself, and the implications of the problem can involve all aspects of human life. This study aims to determine and analyze the effect of people's business credit (KUR), Provincial Minimum Wages (UMP), and PMDN investment on Poverty in Indonesia. The data used in this study are secondary in the 2016-2020 period. The method used is multiple linear regression with a panel data approach with Eviews. The regression output with the fixed-effect model shows that the KUR, UMP, and PMDN variables hurt the poverty level in Indonesia. The UMP variable significantly affects the poverty level, while the KUR and PMDN variables have no significant effect on the poverty level. This finding implies that the government can provide business capital, increase wages and provide vast opportunities for investors, which will reduce Poverty in Indonesia
\end{abstract}

Keywords: People's Business Credit, Provincial Minimum Wage, PMDN, and Poverty

\section{Introduction}

Poverty is a problem in almost all countries in the world, especially in developing countries. Poverty has a multidimensional nature which means that humans have various needs. So Poverty can be viewed from primary aspects such as inferior because of assets, knowledge, skills, and secondary elements, namely in the form of poor social networks, financial resources, and information [1]. BPS data [2], in the period 2010 to September 2020, the poverty rate in Indonesia has decreased, both in terms of numbers and percentages, except in September 2013, March 2015, March 2020, and September 2020. the portion of poor people in September 2020 increased to 10.19 percent, an increase of 0.41 percent in March 2020, and a rise of 0.97 percent in September 2019. The number of poor people in September 2020 amounted to 27.55 million people, an increase of 1.13 million people against March 2020 and an increase of 2.76 million people against September 2019.

The complex nature of the poverty problem demands integrated policies and strategies for overcoming, for example, through programs to expand productive employment opportunities, human empowerment, and easy access to various existing socio-economic options. Due to various government limitations, poverty alleviation programs or policies oriented to poverty problems require a priority scale. Poverty has been exposed and is a matter of debate. Poverty has been defined differently and reflects a spectrum of ideological orientations. Even a quantitative approach to defining Poverty has been debated extensively by several researchers interested in this issue [3].

Reducing the level of Poverty that occurs in society is one of the main objectives of public policies carried out by each region and nationally. Government public policies are essential in 
overcoming Poverty, namely fiscal or budget policies. One aspect of budget policy is partiality, namely taking sides with all levels of society, including the poor. The pro-poor government budget is an essential instrument for policymakers to overcome the problem of Poverty [4].

The government implements various poverty reduction programs by providing subsidies to the community as a government tool in the context of income retribution for equalization; however, at the implementation stage, this is very doubtful if it is related to the facts that occur in the life of Indonesian people which are still very far from the prosperous category. UMKM has a substantial contribution to the national economy. UMKM is dominated by micro-business actors, amounting to $98.68 \%$, with a workforce absorption of around $89 \%$. Meanwhile, the contribution of micro-enterprises to GDP is only about $37.8 \%$. Microbusinesses also have fast transaction turnover, use domestic products, and are in contact with the primary needs of the community. To that end, the GovernmentGovernment adopted several policies, including subsidizing loan interest, restructuring credit, providing working capital guarantees, and tax incentives. Interest subsidies are provided to strengthen the capital of UMKM through People's Business Credit (KUR).

KUR is the Government'sGovernment's step in encouraging the expansion of access to formal financial services for the adult population in Indonesia. Through these programs, it is hoped that the poverty rate will further decline and economic growth will be more evenly distributed, as stated [5], [6], [7]. Some of the efforts being made by the Indonesian GovernmentGovernment are to move the real sector through the UMKM sector with the KUR program policy, which will ultimately result in reducing the poverty rate.

Another effort to understand Poverty in Indonesia is through the production approach. The production approach can be reflected in the minimum wage policy, which gives each region the freedom to determine the size of the UMP/UMR. Unlike previous years, at the end of 2020, the GovernmentGovernment announced not to increase the 2021 minimum wage increase.

In several empirical studies, there are several studies against minimum wage policies, including [8] states that the minimum wage will depress the distribution of income and generate debate whether labor absorption will be subject to high labor costs, reduced profits, and reduced labor or increase the price of output which in turn burdens the poor. Several researchers stated the same thing ([9], [10], [11], and [12]). In addition, the low level of public capital formation is alleged to be one of the Causes of Poverty. Capital is interpreted as an investment, as quoted by Nurkse [13]: that, "The transfer of some of the existing resources in society to increase the supply of goods in such a way as to expand output in the future," then [14], states that "the change in time capital is an investment". The effect of investment on growth and welfare is the empirical finding of several researchers, such as [15], [16], [17], [18]. The discussion of investment to Poverty and yields mixed conclusions [19] dan [20]. So it is interesting to see the effect of the KUR subsidy policy, minimum wages, and pro-poor investment in a province on the quality of poverty management in Indonesia.

\section{Literature Review}

Poverty becomes an effect relationship, and a causal relationship forms a paradigm circle of Poverty. This poverty paradigm circle illustrates that Poverty is caused itself, "The vicious circle of Poverty." This Poverty paradigm circle is a picture of infinite causality so that can be explained as follows; low domestic people's income due to low productivity results in increased Poverty, causes the household saving rate to below, cause the level of domestic investment to 
down, domestic capital flowing to below in an area resulting in a region lack of money. Results in a decrease in domestic productivity to be low, low domestic productivity resulting in low domestic income, and so on, thus forming a circle of poverty paradigm. This Poverty paradigm circle is a picture of infinite causality so that can be explained as follows; low domestic people's income due to low productivity results in increased Poverty, causes the household saving rate to below, cause the level of domestic investment to down, domestic capital flowing to below in an area resulting in a region lack of money. Results in a decrease in domestic productivity to be low, low domestic productivity resulting in low domestic income, and so on, thus forming a circle of poverty paradigm.

Ragnar Nurkse (1953) in [21] argues that an emerging country is poor because it is deficient (an emerging country is poor because it is imperfect); Poverty in a country has no end, meaning that an emerging country is because it has nothing, and by having nothing causes a state suffering from Poverty. Argues that an emerging country is poor because it is deficient (an emerging country is poor because it is imperfect); Poverty in a country has no end, meaning that an emerging country is because it has nothing, and having nothing causes a state suffering from Poverty.

Not all Poverty means that people or groups considered flawed are the people who suffer the most on the earth's surface. Poverty is then divided into several types [22], namely; Relative Poverty is a condition of Poverty due to the influence of development policies that have not reached all levels of society, which causes inequality in income distribution. Absolute Poverty is a condition that is determined based on the inability to fulfill the minimum basic needs such as food, clothing, and health necessary to live and work. Structural Poverty is Poverty caused by unfavorable life structure or structure conditions and causes Poverty and perpetuates Poverty in society. Cultural Poverty is a condition of Poverty caused by the customs and culture of a particular area that is shackled and closely attached to the poverty indicator.

The Government'sGovernment's role in poverty alleviation is urgently needed, Government'sGovernment's role, namely allocation, distribution, and stabilization. This role is a condition that must be fulfilled if the development goal, namely poverty alleviation, is to be resolved. The budget issued through spending for poverty alleviation becomes a stimulus in reducing Poverty and several other development issues. [23], emphasizes the role of the funding for poverty alleviation. The findings of this study explain the negative relationship between budgetary income and the number of poor people. This means that the higher the amount of the income budget, the lower the poverty level. Of course, the funding in question is allocated to create poverty alleviation programs, both short and long-term. What Hasibuan discovered was corroborated by [24]. Alawi found that budget allocations for community empowerment programs have a negative correlation with the severity of Poverty. This means that the higher the budget allocation for community empowerment programs, the lower the severity of Poverty. (Erwan, 2010) in [25], which further explains that a subsidy is a provision (contribution) in the form of money or finance provided by the government or a public body.

At the beginning of the implementation of the KUR Program, it was part of a pro-poverty policy by encouraging the expansion of access to capital informal financial institutions. In this program, the government made various policy changes by the direction of the procedure for empowering micro and small businesses. These multiple changes touched different aspects of basic policies, including changes to the KUR distribution scheme, expanding the coverage of KUR program recipients, expanding the channeling institutions of the KUR Program. Efforts to broaden were also carried out by encouraging the active role of local governments to make various facilitation efforts to optimize the distribution of KUR [26]. These multiple efforts, of course, resulted in changes and dynamics in distributing the KUR Program [27] found that an 
increase in the minimum wage increased welfare loss; in addition, it was also found that the minimum wage reduces equity for people with high and low education. Previous [8] states that the minimum wage will depress the distribution of income and generate debate whether labor absorption will be subject to high labor costs, reduced profits, reduced labor, or increased output price. Investment is defined as spending to buy capital goods and production equipment to produce goods and services in the future [28]. Keynes also used this definition [29] added that a large stock of physical capital resulting from high investment ratios would lead to high GRDP. Increased investment also tends to lead to high income.

\section{Research Methods}

The method in this research is using panel data regression. Panel data is a combination of time series and cross-section data. The data used is secondary data from BPS. The object of this research is Poverty, KUR, UMP, PMDN against Poverty in Indonesia in 2016-2020. The following is the definition of the research variables:

1. Poverty is a measure of the average expenditure gap of each poor person against the poverty line. The higher the index value, the farther the population's average expenditure is from the poverty line (Poverty Depth Index = P1), measured in percent.

2. KUR is the amount of people's business credit realized in the province, measured in rupiah.

3. UMP is, according to the Ministerial Regulation Manpower and Transmigration No. 7 of 2013, namely, the lowest monthly wage consisting of the basic salary including a fixed allowance which the governor determines as a safety net, measured in rupiah.

4. Investment is the amount of private investment in a province measured by domestic investment, measured in rupiah.

Panel data multiple linear regression is a combination of time series data and cross-section. The following is the research equation formula:

$K E M i t=\beta 0+\beta 1 K U R 1 i t+\beta 2 \mathrm{UMP} 2 i t+\beta 3 \mathrm{PMDN} 3 i t+\varepsilon i t$

Where:

$\mathrm{KEM}=$ poverty that is $\mathrm{P} 1$ (Persen)

KUR $=$ KUR t realized (Rupiah)

$\mathrm{UMP}=$ Provincial Minimum Wage (Rupiah)

Investment $=$ PMDN (Rupiah)

$\beta 0=$ Constanta

$\beta 1, \beta 2, \beta 3=$ regression coefficient

$\varepsilon=$ error term

There are units and quantities of independent variables in this study, so a natural logarithmic model is created. Natural logarithms aim to avoid heteroscedasticity and can determine the coefficient that shows elasticity. From these considerations, the equation in this study becomes: InYit $=\beta 0+\beta 1 \operatorname{In} \mathrm{KUR} 1 i t+\beta 2 \operatorname{In} \mathrm{UMP}+\beta 3 \operatorname{InPMDN} 3 i t+\varepsilon i t$ 
Model estimation technique has three techniques: the OLS (Common Effect) method, the Fixed Effect model, and the Random Effect model. Then using a better design, done with the Hausman Test [30]

\section{Results and Discussion}

The regression analysis results were carried out using the fixed-effect model and had passed the classical assumptions. It can be described further about the effect of each independent variable on the dependent. The following Table 1 shows a summary of the regression output used in this study.

Table 1. Fixed Effect Model Regression Output

\begin{tabular}{cccc}
\hline Variabel & Koefesien & TStatistik & Prob. \\
\hline KUR & $-0,030$ & $-0,547$ & 0,585 \\
UMP & $-0,449$ & $-2,020$ & 0,045 \\
PMDN & $-0,032$ & $-1,366$ & 0,174 \\
\hline
\end{tabular}

R-Square $=0,982$

Adjusted R-Squared $=0,977$

With the regression result formula

$\mathrm{Y}=10,355-0.030 \mathrm{KUR}-0.449 \mathrm{UMP}-0.032 \mathrm{PMDN}$

The value of the KUR regression coefficient is -0.030 , which means that KUR hurts Poverty, meaning that if the KUR increases, it will reduce Poverty. The variable which significantly affects Poverty is slang. Less than 0.1 with a confidence level of $90 \%$, so KUR is an insignificant variable on Poverty. As stated [5], [6], [7] that KUR is a government step in encouraging the expansion of access to formal financial services for the adult population in Indonesia. Through these programs, it is hoped that the poverty rate will further decline and economic growth will be more evenly distributed; some of the efforts being made by the Indonesian government are to move the real sector through the UMKM sector with the KUR program policy, which will ultimately result in reducing the poverty rate.

At the beginning of the implementation of the KUR Program, it was part of a pro-poverty policy by encouraging the expansion of access to capital informal financial institutions. In this program, there have been various policy changes made by the GovernmentGovernment by the direction of the policy for empowering micro and small businesses. These multiple changes touched different aspects of basic procedures, including changes to the KUR distribution scheme, expanding the coverage of KUR program recipients, expanding the channeling institutions of the KUR Program. Efforts to broaden were also carried out by encouraging the active role of local governments to make various facilitation efforts to optimize the distribution of KUR [26]. These multiple efforts, of course, resulted in changes and dynamics in distributing the KUR Program.

The UMP regression coefficient value is -0.449 , which means that the UMP hurt Poverty, meaning that it will reduce the poverty rate if the UMP increases. The variable which significantly affects Poverty is slang. Less than 0.1 with a confidence level of $90 \%$, so the UMP is a variable that significantly affects Poverty. Contrary to [8], who states that the minimum 
wage will depress the distribution of income and generate debate whether labor absorption will be subject to high labor costs, reduced profits, and reduced labor or increase the price of output, which burdens burdens the poor. Several researchers stated the same thing ([9], [10], [11], and [12]).

The PMDN regression coefficient value is -0.032 , which means that PMDN hurt Poverty, meaning that if the PMDN increases, it will reduce Poverty. The variable which significantly affects Poverty is slang. Less than 0.1 with a $90 \%$ confidence level, PMDN is an insignificant variable on Poverty. By the low level of community capital formation, which is believed to be one of the causes of Poverty, this capital is interpreted as an investment, as quoted by Nurkse. [13] : "The transfer of some of the existing resources in society to increase the supply of goods in such a way as to expand output in the future," then [14], states that "the change in time capital is an investment. The adjusted R-squared value shows that $97.7 \%$ of the independent variables can explain the dependent variable, and outside the model, explain the remaining $2.3 \%$.

\section{Conclusion}

This study concludes that the variables KUR and PMDN do not significantly affect the level of Poverty. At the same time, the UMP has a significant adverse effect on the level of Poverty in Indonesia. This result implies that the provincial government also needs to increase people's income through the capital provided and domestic investment, namely by creating job opportunities and giving easy procedures for investors. The provision of money will create business opportunities and will Reduce Poverty. Making policies related to the ease of credit procedures to make it easier for small businesses to get capital will encourage an increase in the economy to reduce Poverty.

\section{References}

[1] L. Arsyad, Dasar-Dasar Ekonomika Pembangunan. Yogyakarta: UPP STIM YKPN, 2010.

[2] Badan Pusat Statistik Indonesia, Data Kemiskinan. Indonesia: BPS Indonesia, 2021.

[3] Pandji Indra, "An Analysis Towards Urban Poverty Alleviation Program in Indonesia," University of Southern California, 2001.

[4] I. Maipita, Mengukur Kemiskinan dan Distribusi Pendapatan. Yogyakarta: UPP STIM YKPN, 2014.

[5] M. Saleh, "Upaya Penanggulangan Kemiskinan Melalui Pembardayaan Sektor Umkm," J. Muamalah, vol. 5, no. 2, pp. 170-177, 2015.

[6] Damayanti dan Adam, "Program Kredit Usaha Rakyat (KUR) sebagai Alat Pendorong Pengembangan UMKM di Indonesia," no. April, pp. 1-50, 2015.

[7] I. Iztihar, "Analisis pengaruh kredit usaha rakyat terhadap penanggulangan kemiskinan, pengembangan usaha kecil dan perekonomian di indonesia," Universitas Brawijaya Malang, 2018.

[8] C. Brown, Minimum Wages, Employment, and the Distribution of Income. North-Holland: New York and Oxford: Elsevier Science, 1999.

[9] Dickens et al, "The Effects of Minimum Wages on Employment: Theory and Evidence from Britain," J. Labor Econ., vol. Vol. 17, pp. 1-22, 1999.

[10] S. Lemos, "The Effect of the Minimum Wage on Prices," IZA Ger., p. 1072, 2004.

[11] G. RK, Vedder \& LE, Does The Minimum Wage Reduce Poverty? Ohio: Ohio University, 2001.

[12] Sabia et al, "Are the Effects of Minimum Wage Increases Always Small? New Evidence from a Case Study of New York State," Ind. Labor Relations, vol. Vol 65 No., pp. 350-376, 2010. 
[13] Jhingan ML, Ekonomi Pembangunan dan Perencanaan, Edisi 14. Jakarta: PT RajaGrafindo Perkasa, 2012.

[14] B. \& S. Martin, Public Finance in Models of Economic Growth. NBER, 1990

[15] O. Blanchard and A. Shleifer, "Federalism With and Without Political Centralization: China Versus Russia," vol. 48, 2001.

[16] J. Bessen and E. Maskin, "Sequential Innovation, Patens, and Imitation," Work. Pap. Econ., vol. 40, no. 00, pp. 611-635, 2000.

[17] Q. He and M. Sun, "Does fiscal decentralization increase the investment rate? Evidence from Chinese panel data," Ann. Econ. Financ., vol. 19, no. 1, pp. 75-101, 2018.

[18] H. Wang, Q. Zhao, Y. Bai, L. Zhang, and X. Yu, "Poverty and Subjective Poverty in Rural China," Soc. Indic. Res., vol. 150, no. 1, pp. 219-242, 2020, doi: 10.1007/s11205-020-02303-0.

[19] W. Easterly and S. Rebelo, "Fiscal Policy and Economic Growth: an Empirical Investigation," Journal of Monetary Economics, vol. 32, no. 3. NBER Working paper, Cambridge, pp. 417458, 1993.

[20] P. R. Agénor, N. Bayraktar, and K. El Aynaoui, "Roads out of poverty? Assessing the links between aid, public investment, growth, and poverty reduction," J. Dev. Econ., vol. 86, no. 2, pp. 277-295, 2008, doi: 10.1016/j.jdeveco.2007.07.001.

[21] Kuncoro, "Bribery and Time Wasted in Indonesia: A Test of the Efficient Grease Hypothesis," Econ. Financ. Indones. LPEM-FEUI, vol. Voi. 52 No, pp. 31-53, 2004.

[22] Badaruddin, Ekonomika Otonomi Daerah, Edisi 1. Yogyakarta: UPP STIM YKPN, 2012.

[23] M. S. . Hasibuan, Ekonomi pembangunan dan Perekonomian, Edisi Revi. Jakarta: Bumi Aksara, 2005.

[24] N. Alawi, "Pengaruh Anggaran Belanja Pembangunan Daerah Terhadap Kemiskinan Studi Kasus: Kab/Kota di Jawa Tengah tahun 2002-2004,” Universitas Indonesia, 2006.

[25] D. Munawar, "Memahami Pengertian dan Kebijakan Subsidi dalam APBN," 2013.

[26] Aristanto E, "Kredit Usaha Rakyat (KUR): Pilihan Kebijakan Afirmatif Mendorong Pengembangan Usaha Mikro, Kecil dan Menengah di Indonesia," J. Bank. Financ., vol. 1(1), pp. 10-23, 2019.

[27] et all Golan A, "Walfare Effects of Minimum Wage and Other Government Policies," Inst. Res. Labor Employ., 2001.

[28] Mankiw, Macroeconomics. New York: Worth Publisher Inc, 2003.

[29] M. Kuncoro, Metode Riset untuk Bisnis dan Ekonomi, Edisi 4. Jakarta: Erlangga, 2013.

[30] D. N. Gujarati, Basic Econometrics. New York: Mc Graw-hill Companies, 2010. 